\title{
Study of Relationship of Self-Concept and Academic Performance of Distance Learners
}

\author{
Saba Shamim Qureshi \\ Department of School Education, Punjab \\ Dr. Naila Naseer \\ Lecturer Distance \\ Department of Non-Formal \& Continuing Education, AIOU \\ naila.naseer@aiou.edu.pk
}

\begin{abstract}
Current research explored correlation between distance learners' self-concept and academic performance at post graduate level (M.A Education). The purpose of this research was to find out relationship between self-concept of students and their academic achievement. This was a quantitative study which used questionnaire as main tool of data collection along with the analysis of end of term result of students. To achieve the purpose of the study, distance learners (240) of Master in Education (M.A.) of AIOU were randomly selected by employing table of random numbers for sample selection. The study was delimited to Islamabad region and Rawalpindi region respectively. Data was collected through "Self-Concept Scale" developed by researchers. National language (Urdu) was used in the scale to make it more understandable for the respondents. The prototype of the scale was also content validated. In this regard, opinions of five educational experts were sought and their suggestions were incorporated in the final version of prototype. Data collection process was done through mail. Academic achievement was measured in three courses' results $0512,0652 \& 0655$. For data analysis, Pearson correlation was used. Analysis of results showed statistically significant positive relationship between self-concept of distance learners and their academic achievement. It was recommended that the future research and development studies may be conducted to design training programs for distance learners to enhance their self-concept.
\end{abstract}

Key Words: Distance Learners, Self-Concept, Higher Level, Academic Achievement

\section{Introduction}

Open Distance learning is unique study system in which correspondence fills the remoteness among teachers and students. This physical gap does not create educational gap hence it is filled up by continuous guidance, tutorials and use of multimedia packages. This distance is a pre-requisite for distance education to happen. When tutors and learners are at a physical distance; the use of technology and occasional instructional face-to-face communication bridges the distance (Willis, 2001). Since, DE is an instructional experience that is planned by the physical distance and students are separated from the tutors. There is diversity in the use of teaching strategies and modes i.e. online courses, the use of videoconferencing, correspondence through 
print media and broadcast media etc. however, no consensus on a single definition of distance education is found in literature. In this regard, Liu (2008, para 3) elaborated the concept of DE as "distance education is also called distance learning, e-learning or online learning. Unlike conventional classroom learning, it is not bounded by space and time. In fact, teachers and students are commonly separated by space and time, although they may choose to interact synchronously or meet periodically over the length of the course. Distance learning also needs to use technology. In the early days of distance education, radio and television were the media used to conduct educational activities. Currently, the methods have extended to the internet, email, software, video, tapes, cameras, etc. In comparison, instructors and students may choose to use technology in a conventional classroom teaching but is optional".

Nowadays, the concept of DE has emerged as a separate medium of instruction, training and education. In any educational system, the basic aim of giving good output to students is assessed in terms of their grades/academic achievement. Student's improvement in academic achievement is major concern of almost every educational system. It also determines the attainment of desired level of improvements in studies, attitudes, behaviors etc. academic achievement is also important for teachers and institutions as it may determine their good or bad repute. Parents are also very touchy regarding academic achievement of their children (The University of Wisconsin System Institutions, 2000). Wide range of factors influence on learners' academic achievement i.e. social, economic, psychological and psychosocial etc. Psychological factors may vary in numbers, but self-concept is the variable, which may be an important one. The term self-concept is conceived differently. Bailey (2003) states that the qualities which are present in a person is called self-concept. It is not assessed by measurement it is estimated. Ackerman (2020, para.4) stated that self-concept is perception of his/her self; 'a person's self-image is based on how they see themselves, while self-concept is a more comprehensive evaluation of the self, largely based on how a person sees themselves, values themselves, thinks about themselves, and feels about themselves'.

According to Larson and Buss (2005) self-concept is also ones' own perception and image. It is a simple answer to a question "Who am I". A person develops it from infancy till death. Eysenck (2001) called it total image of ones' self: "self-concept is all of the thoughts and feelings about the self; it combines self-esteem and self- image (p.341)".Valencia (2008) extended it to mental and conceptual insightfulness of a person about him/herself. Santrock (2001) called it a 
specific view on specific domains of one's self, "Self-concept is domain-specific evaluations of the self (p. 302)". The notion of self-concept was later on associated as academic self. In this regard, Alice (2006) said that 'academic self' plays great role in academic achievement of students. This academic self-concept he regarded as a perception students develop about their academic capabilities and potentials. Therefore, their academic self leads them towards success or failure. The feelings, which an individual has about his/herself, are considered as self-concept. Many factors influence on a persons' self-concept. These may include social factors, psychological factors and economic factors. Society, including home, parents, family, siblings, school, teachers and peers may improve or affect students' self-concept. So, self-concept may be considered as controversial psychological issue in students' academic performance. Different psychologists have explored it in different educational settings and in variety of social and cultural surroundings with different variables. Different studies indicated that students' low grades might be associated with their self-perception because they might not fully understand and grasp the learning materials. In one more study, adolescence self-concept was explored and revealed strong correlation with educational performance (Bharathi and Sreedevi, 2018). In another study by Khalaila (2015) similar findings were revealed. Gibson (1996) self-concept was studied on 16 external degree students in distance education settings. Interview was used as a research tool. In this study, detectors and enhancers of self-concept were identified. It was found that in distance education settings; there is an influence of curriculum/content on distance learners' academic self-concept. Ghazvini (2011) revealed similar findings. Rudasill and Callahan (2008) presented contrary findings that students' academic success also happens due to negative self-concept as it can hamper students' choices. In a study by Lyon (1993), statistically strong relationship between self-concept of junior high school students and their academic achievement was reported.

\subsection{Problem Statement}

In any education system, students being living organisms carry many psychological needs i.e. self-respect, self-esteem, self-concept, emotional intelligence etc. Among different psychological variables, self-concept is an essential variable which needs to be catered in every education system for better educational outcomes. Traditional face-to-face teaching caters psychological needs of students by using different techniques and teaching strategies. Unlike faceto-face teaching, DE facilitates learners' educational and psychological needs through distance in which teachers and students are on two continuums. Distance learners gain opportunities of 
independent study, so they may have positive view of their self-concept (Gibson, 1996). Whether or not this assumption implies on distance learners from different cultures especially from Pakistan, there was the need to investigate this issue. So, with this in mind, this research was an effort to examine relationship of distance learners' self-concept and academic achievement.

\subsection{Objectives}

Following objectives were developed to:

- Measure distance learners' self-concept.

- Explore correlation between distance learners' self-concept and academic achievement.

\subsection{Hypothesis}

Ho There is no significant positive correlation between distance learners' self-concept and academic achievement.

\subsection{Significance}

Present study explored a very complex and time-needed phenomena which has its significance for all regions and all populations. During the recent Covid-19 pandemic, educationists are also concerned of exploring the power of self-concept of students. People around the globe are undergoing from various mental traumas and psychological illnesses. This research is significant as it has indicated the importance of students inner "what am I"? The findings of this study would help students to take help to know their inner potentials being distance learners to not only gauge their academic performance but also to boost their self-concept to cope with stressful situations. This study would also shed light on the important role of psychological variable i.e. self-concept for the planners of distance learning so that more importance would be given to include activities related with psychological variables for students so that they may improve their self-concept. This study will be significant for distance education institutions to update their web pages with online trainings, online quizzes, online short courses on self-concept so that students who may be suffering from low level of self-concept would enhance their potential to cope with challenging educational and social circumstances. 


\subsection{Limitations of the Study}

Every research has some limitations. So it was the case with the present research. One of the limitations of the study was that due to data collection through post, desired level of response could not be taken as the distance learners were scattered on two big regions Rawalpindi and Islamabad. The reason to post the scales to respondents was that the workshops start simultaneously all over the Pakistan for only two days per course and it was impossible for the researchers to collect data through personal contact.

\subsection{Delimitations}

Delimitations of this study were:

1. Students (M.A Education) of Allama Iqbal Open University

2. Islamabad and Rawalpindi regions.

\section{Methodology}

Following was methodology of this research:

\subsection{Research Design}

This study employed quantitative research design as questionnaire was used to explore the research problem.

\subsection{Population}

It was comprised on Spring/ $2^{\text {nd }}$ Semester students (800) of M.A Education $\left(2^{\text {nd }}\right.$ Semester, Spring) of three courses (0512, 0652, and 0655) of AIOU from Rawalpindi and Islamabad regions.

\subsection{Sample}

Total number of 30 percent sample was taken by employing random sampling. For this purpose, table of random numbers was also followed. Below is detail of sampling:

\section{Population Sample}

Islamabad Region

249

\section{5}


Rawalpindi Region

Total
551

800
165

204

\subsection{Instrument}

Following research instrument was administered on distance learners to measure their self-concept:

3.4.1. Self-Concept Scale (SCS). This was self-developed scale on self-concept. A pool of items was constructed by consulting literature and 33 items were initially included in first prototype. Then content validity from five educational experts was sought and 8 items were deleted. So, second prototype was comprised on 25 items. It has three subscales "a) self-concept being distance learner; b) academic selfconcept and; c) self-worth". Response pattern of the items of this scale ranged from "1 to 5" strongly agree to strongly disagree (5-point Likert scale). The scoring key was also developed as negatively scored items were 6 and positively scored items were 19. Minimum scale score was 25 and highest was 125 . It was also translated in National language (Urdu).

3.4.2. Validity. The validity of the tool was found through pilot study. A randomly selected sample (M.A Education students of previous Semester) of 50 participants (who were not from the actual sample of the study) was included in pilot study. The instrument was posted to them with a selfaddressed envelope for the quick and timely response. Among 50 respondents, 26 sent back filled questionnaires. Results of pilot study indicated alpha reliability coefficient $\left(.91^{*}\right)$ of the Selfconcept scale. In the subscales of SCS, alpha reliability coefficients were self-worth (.81*), concept being a distance learner $(.78 *)$ and academic self-concept $(.83 *)$.

3.4.3. Reliability. For the reliability of research instrument, after two weeks' interval, the SCS scale was again sent through post with an envelope to the same 50 participants who participated in pilot study. Their responses were correlated and test-retest reliability coefficient was (.86*) which indicated high reliability of the scale.

3.4.4. Variables of the Study. Self-Concept: The sense of self we achieve from ego, experience, and the images we get from opinions and appraisal from others is called self-concept (Petress, 2008). In this research, self-concept was operationalized "a personal image of a distance learner that how he/she viewed himself as a distance learner; their perception of themselves as distance learner in academics and how much they worth themselves". 
Academic Achievement: "It's a student's ability and performance is called achievement, which is reflected in terms of his/her emotional, social, and physical in his/her academic life (Steinberger, 1993)". Present research operationalized academic achievement in terms of the $2^{\text {nd }}$ semester performance of in three courses $(0512,0652 \& 0655)$.

3.4.5. Data Collection Procedure. Data was collected through post. For data collection purpose, list of students along with their addresses was obtained from AIOU authorized sections. From the total number of 800 respondents from two regions (Islamabad and Rawalpindi), 30 percent sample was equally selected randomly by using table of random numbers. In the next phase, research instruments were posted to the selected participants (240). The response rate was104 out of 240 respondents.

\subsubsection{Data Analysis}

In this study, mean, percentages and Pearson correlation were applied to analyze data.

\section{Data Analysis}

Description of data analysis is given below:

Table1. Descriptive Statistics $N=104$

\begin{tabular}{lll}
\hline & Mean & SD \\
\hline Self-concept & 100 & 16.4 \\
Academic Achievement & 341 & 51.2 \\
\hline
\end{tabular}

Table 1 revealed descriptive analysis of self-concept and academic achievement of distance learners. It highlights that distance learners had high self-concept with Mean value 100 and SD 16.4. It also reflected that respondents had Mean of 341 and SD of 51.2 in academic achievement.

Table2. Relationship between Distance Learners'self-concept and Academic Achievement

\begin{tabular}{ll}
\hline & SCS/Self-concept $(\mathrm{r})$ \\
\hline${ }^{*} \mathrm{p} \leq 0.01$ & $.81 *$ \\
\hline
\end{tabular}

Table 2 revealed that there was statistically significant positive relationship between selfconcept and academic performance of distance learners. Pearson $\mathrm{r}$ is $.81^{*}$ which means that there is very strong relationship between the two variables. Increase in one causes increase in other. If 
self-concept of distance learners goes low then their academic performance will ultimately be low and vice versa.

Table 3. Relationship between Sub-Scales of SCS and Distance Learners' Academic Achievement

\begin{tabular}{llll}
\hline & $\begin{array}{l}\text { Self-concept being } \\
\text { distance learner }\end{array}$ & $\begin{array}{l}\text { Academic } \\
\text { Self-concept }\end{array}$ & Self-worth \\
\hline $\begin{array}{l}\text { Academic } \\
\text { Achievement }\end{array}$ & $.74 *$ & $.83 *$ & $.81^{*}$ \\
\hline${ }^{*} \mathrm{p} \leq 0.01$ & & &
\end{tabular}

Table 3 indicated that in all the three subscales of self-concept scale, there was statistically significant positive correlation. However, among these three subscales, academic self-concept was highly strongly correlated $(.83 *)$ with academic achievement which means that this aspect of distance learner play more role in their academic success. The other two subscales Self-concept being distance learner indicated correlation coefficient values of .74* and self-worth .81* respectively. It indicates that all three subscales are interlinked and jointly play role in academic performance of distance learners.

\subsection{Discussion}

This study explored relationship between distance learners' self-concept and academic achievement. Study findings revealed that distance learners had high self-concept. So the null hypothesis was rejected. The results revealed an overall positive significant relationship between self-concept and academic achievement of students. Description of the results (Table 2) indicated that the variables of academic achievement and self-concept are correlated with each other and distance learners had statistically significant strong correlation between these variables. It showed these variables are largely dependent of each other and the presence of high level of one variable indicates the presence of high level of other variable i.e. high level of self-concept confirms the presence of high achievement. In other words, lower the self-concept the lower is the academic achievement. Similar findings are reported by Grum and Musek (2001). In their research, strong positive correlation is reported between self-concept and different indices of personality.

Contrary findings are also found by Zahra, Arif, and Yousaf (2010). They explored bachelor level students' self-concept and educational performance. Study indicated weak relationship in self-concept and students' educational performance. In one more study, Sagar 
(2014) also revealed slight correlation between respondents' self-concept and academic achievement. So, from present research findings, it can be inferred that distance learners' achievement may be affected by different other psychological, social, psycho-social and personal variables i.e. monthly income, marital status, family background, level of schooling etc. but the strong variable which is associated with performance is self-concept. If a student has low level of self-concept, his/her academic performance would also be low.

In this study, the phenomena of self-concept was explored in three subscales "a) selfconcept being a distance learner, b) academic self-concept and c) self-worth" with academic achievement. In table 3, high correlation value among all the three sub-scales of SCS and distance learners' academic achievement inferred that in the first subscale (self-concept being distance learners), respondents had high correlation with achievement. It is said that if self-concept of distance learners decreases then academic achievement is also affected negatively. In the second subscale of Self-Concept Scale "academic self-concept", strong positive relationship indicated that distance learners had high association between these two variables, i.e. if there is high academic self-concept then there will be higher academic performance. Lower the academic self-concept then there would be low academic performance. It means that apart from different other intervening variable which affect academic performance of students is academic self-concept. Academic self-concept is strongest variable with academic performance. Discussion on the results in the light of other researches revealed that self-concept is powerful variable which influences distance learners' achievement. Description of subscales and their relationship with academic performance also highlighted that since distance learners study from distance, so their high selfconcept is also contributing factor in their academic performance. So, it might not be surprising that DE promotes not only autonomy and independence however distance learners also develop high self-concept. Previous researches conducted by Lyon (1993) found strong correlation between self-concept and performance of students however; study of Rinn (2007) indicated average relationship between these two variables. Palomino (2017) also found strong relationship between these two variables.

\section{Conclusions}

Based on the study findings, it is concluded that distance learners exhibited high selfconcept. It is also concluded that distance learners' strong predictor of achievement is self-concept. 
High self-concept leads towards high educational performance. Distance learners with low selfconcept suffer from low academic performance. Correlation in subscales of self-concept scale led to the conclusion that academic self-concept is highest in these scales which contributes in performance. Following is recommended:

1. Since self-concept is strongly correlated with performance of students, so the study suggested that the importance of this important psychological variable may be considered by the distance education institutions. Especially when there is Covid-19 and people need to know about their self-concept. This study would be important to indicate distance learners' self-concept as important contributor in their studies.

2. The study findings are quite significant for the distance tutors/teachers to play their role to plan training sessions to boost self-concept and remove negative emotions from distance learners. In this regard, it is suggested that counseling sessions and tutorials may be tailored on improving and enhancing distance learners self-concept.

3. Importance of psychological variables cannot be neglected. Especially self-concept may be considered important while curriculum planning or curriculum and designing academic activities.

4. Importance of variables of this study may be highlighted by distance teachers and trainings of distance tutors and teachers may be arranged by distance education institutions to highlight the importance of this aspect of distance learners.

5. Some exercises may be uploaded on distance education institutions' websites frequently, so that the self-concept of distance learners may be gauged frequently.

6. Future researches should be conducted to assess the different dimensions of self-concept with other variables to study the phenomena in depth.

\section{References}

Ackerman, C. E. (2020). What is Self-concept theory? Retrieved from https://positivepsychology.com/self-concept/

Alice, K. J. (2006). Relationship between Academic Self-Esteem and English and Mathematics Performance of Adolescents. Retrieved from http://www.brad.ac.uk/hub/studentnews/adolescents.doc 
Bailey, J. H. (2003). Self-Image, Self-Concept, and Self-Identity Revisited. Retrieved from http://www.jablifeskills.com/docs/med-journal2.pdf.

Bharathi, T. A., \& Sreedevi, D. P. (2018). A study on the self-concept of adolescents. International Journal of Science and Research (IJSR)Retrieved from https://www.researchgate.net/publication/324561798_A_Study_on_the_SelfConcept_of_Adolescents

Eysenck, M. W. (2001). Simply Psychology. United Kingdom: Psychology Press Ltd.

Ghazvini, S. D. (2011). Relationships between academic self-concept and academic performance in high school students. Procedia Social and Behavioral Sciences (15), 1034-1039. Retrieved from https://doi.org/10.1016/j.sbspro.2011.03.235

Gibson, D. (1996). Toward an Understanding of Academic Self-Concept in Distance Education.American journal of distance education, (10)1. Retrieved from www.ajde.com/contents/vol10 1.htm

Grum, D. K., \& Musek, J. (2001). Self-concept and academic achievement: Slovenia and France. Retrieved from https://www.researchgate.net/publication/223388331_Selfconcept_and_academic_achievement_Slovenia_and_FranceDOI: $\quad$ 10.1016/S01918869(00)00081-7

Hamachek, D. (1991). Encounters with the Self. (4 ${ }^{\text {th }}$, ed.). New York: Brace Jovanovish publishers.

Hamachek, D. (1995). Self-Concept and School Achievement: Interaction Dynamics and a Tool for Assessing the Self-Concept Component.AmericanJournal of Counseling \& Development, 73, 419425.

Khalaila R. (2015). The relationship between academic self-concept, intrinsic motivation, test anxiety, and academic achievement among nursing students: Mediating and moderating effects. Nurse Education Today 35(3), 432-438.

Larson, R. J., \& Buss D. M. (2005). Personality Psychology: Domains of Knowledge about Human Nature. USA: McGraw Hill.

Liu, S. L. (2008). Student Interaction Experiences in Distance Learning Courses a Phenomenological Study

Lyon, M. A. (1993).Academic Self-Concept and its Relationship to Achievement in a Sample of Junior High School Students. Journal of Educational and Psychological Measurement, (53)1, 201-210. Retrieved from www.online.sagepub.com/cgi/reprint/53/1/201.

Palomino, M. D. C. P. (2017). An Analysis of Self-Concept in Students with Compensatory Education Needs for Developing a Mindfulness-Based Psycho-educational Program. Retrieved from https://doi.org/10.1177/2158244017708818

Petress, K. (2008). Discussion of Self. Retrieved from http://www.umpi.maine.edu/ petress/sconcept.pdf

Rudasill, K., \& Callahan, H. (2008). Psychometric Characteristics of Harter Self-Perception Profiles for Adolescents and Children for Gifted Populations. Canadian Gifted Child Quarterly.(52)1. Retrieved from http://gcq.sagepub.com.

Sagar, M. M. H. (2014). Relationship between Self-concept and Academic Achievement among the Secondary School Students of Dhaka City. International Journal of Interdisciplinary and Multidisciplinary Studies (IJIMS), 1(9), 95-98. Retrieved from 
https://www.researchgate.net/publication/307882817_Relationship_between_Selfconcept_and_Academic_Achievement_among_the_Secondary_School_Students_of_Dha ka_City

Santrock, J.W. (2001). Adolescence. ( $8^{\text {th }}$, ed.) New York: McGraw-Hill Companies.

Shah, k., \& Param. J. S. (2002). Theories of Motivation. Retrieved from http://www.analytictech.com/mb021/motivation.htm.

University of Wisconsin System institutions, (2000). What is Distance Education? Retrieved September 20, 2008 fromwww.IPSE.edu.com.

Valencia, C. (2008). Self-Concept and Self-Esteem. Retrieved fromhttp://www.selfesteemawareness.com/self-concept.htm.

Willis, B. (2001). Introduction to Distance Education. Retrieved September 25, 2007 from www.bwills/uidaho.edu.

Zahra, A., Arif, M.H., \& Yousaf, M. I. (2010). Relationship of Academic, Physical and Social Self-Concepts of Students with their Academic Achievement. Contemporary Issues in Education Research, 3(3). 73-78. Retrieved from https://files.eric.ed.gov/fulltext/EJ1072594.pdf 